\title{
Measurement of Radon Exhalation Rate in Some Building Materials Using Nuclear Track Detectors
}

\author{
Hesham A. Yousef 1 , A. H. El-Farrash², A. Abu Ela², Q. Merza² \\ ${ }^{1}$ Physics Department, Faculty of Science, Suez University, Suez, Egypt \\ ${ }^{2}$ Physics Department, Faculty of Science, Mansoura University, Mansoura, Egypt \\ Email: h_yosef2013@yahoo.com
}

Received 20 April 2015; accepted 30 June 2015; published 3 July 2015

Copyright $@ 2015$ by authors and Scientific Research Publishing Inc.

This work is licensed under the Creative Commons Attribution International License (CC BY). http://creativecommons.org/licenses/by/4.0/

(c) () Open Access

\begin{abstract}
In this paper, forty samples of building materials collected from local market in Dakahlia Governorate, Egypt. The radon concentration in these samples were measured using solid state nuclear track detector. Solid state nuclear track detectors have become an important tool in every investigation of the radon levels in the surrounding environment. The obtained results have shown that the highest average of radon concentration in granite samples and the average value is 845.43 $\mathrm{Bqm}^{-3}$, while the lowest average value is white cement $68.42 \mathrm{Bqm}^{-3}$. The present work is important to detect any harmful radiation in our houses that affect human and to establish a data base for building materials which, used in a local market. The obtained results show that the radon concentrations of the most samples are below the allowed limit of ICRP.
\end{abstract}

\section{Keywords}

Radon, Radioactivity, Building Materials, Radiation, LR-115

\section{Introduction}

Radon is a natural noble gas has three main natural isotopes namely, radon $\left({ }^{222} \mathrm{Rn}\right)$ decay product of ${ }^{238} \mathrm{U}$ series, thoron $\left({ }^{220} \mathrm{Rn}\right)$ produced from decay of ${ }^{232} \mathrm{Th}$ series and ${ }^{219} \mathrm{Rn}$ a decay product from the chain originating with ${ }^{235} \mathrm{U}$ [1]. ${ }^{222} \mathrm{Rn}$ isotope has a half-life of 3.82 days while ${ }^{220} \mathrm{Rn}$ isotope has a half-life of 55 seconds and ${ }^{219} \mathrm{Rn}$ isotope has a half-life of about 3.9 seconds. Radon and its daughter products may pose a significant health hazard especially when concentrated in some enclosed areas such as underground mines, caves, cellars or poorly ventilated and badly designed houses. Thus radon concentration in dwellings is important due to the health risk 
and to determine the design of control strategies [2].

The valuation of radiological risk related to inhalation of radon and radon progeny is based mainly on the integrated measurements of radon. Therefore, it is desirable not only to measure the radon but also to find out the sources of radon especially in the houses [3]. Radiation exposure due to natural radionuclides in building materials like radon concentration in closed space was recognized as a significant cancer risk for the general population [4].

Ionizing radiation levels in buildings related to radionuclide content in building material samples is clearly of fundamental importance in the assessment of population exposure as most of the residents spend about $80 \%$ of their time indoors [5].

The present study aimed to determine the radon concentrations and radon exhalation rate in some building materials from local market of Dakahlia Governorate, Egypt, in order to detect any harmful radiation effects on the human and establish a data base for building materials which, is used in a local market.

\section{Materials and Methods}

Solid state nuclear track detectors have become an important tool in every investigation of the radon levels in the surrounding environment. Can technique with LR-115 detector was used to determine radon concentration and radon exhalation rate of the most commonly used building materials in Dakahlia Governorate. All samples were crushed to a grain size $1 \mathrm{~mm}$ and placed into samples containers. All samples were dried in oven at $110^{\circ} \mathrm{C}$ for $3 \mathrm{hr}$, minced, sieved, weighted and carefully sealed for 61 days in cylindrical containers of plastic with dimensions of $9 \mathrm{~cm}$ in diameter and $16 \mathrm{~cm}$ in depth. The plastic container was capped tightly by an inverted cylindrical plastic cover.

A piece of LR-1115 (manufactured by Kodak Pathe, France) detector of area $(1.5 \times 1.5) \mathrm{cm}^{2}$ fixed at the bottom center of the inverted plastic cover. During the exposure time of $\alpha$-particles from the decay of radon and their daughters bombard the LR-115 detector in the air volume of the cylindrical containers. The detectors were collected after the irradiation period and etched in $\mathrm{NaOH}$ solution $2.5 \mathrm{~N}$ at $60^{\circ} \mathrm{C}$ for one hour [6]. After etching the LR-115 detectors were washed in distilled water and wash time make a final rinse in distilled water and ethyl alcohol solution (1:1) during 2 minutes at $20^{\circ} \mathrm{C}$ and dried in air. The track density was determined using optical microscope at $640 \times$ magnification which was calibrated before usages. The background of LR-115 track detector was counted by optical microscope and subtracted from the count of all detectors. Radon concentration in the samples was calculated using the following formula [7]:

$$
C_{R n}=\frac{\rho}{\eta T}
$$

where, $C_{R n}$ is radon concentration $\left(\mathrm{Bqm}^{-3}\right), \rho$ is the track density $\left(\right.$ track $\mathrm{cm}^{-2}$ ), $\mathrm{T}$ is the exposure time (day) and $\eta$ is the calibration coefficient of LR-115 detector obtained from the experimental calibration 0.056 tracks $\mathrm{cm}^{-2} \cdot \mathrm{day}^{-1} / \mathrm{Bqm}^{-3}$ of radon [6]. The surface exhalation rate $\left(\mathrm{Bqm}^{-2} \cdot \mathrm{h}^{-1}\right)$ in the building material samples was calculated using the following formula:

$$
E_{\mathrm{A}}=\frac{C V \lambda}{A T_{\text {eff }}}
$$

where, $E_{A}$ is the surface exhalation rate in $\left(\mathrm{Bqm}^{-2} \cdot \mathrm{h}^{-1}\right), C$ is the integrated radon exposure in $\left(\mathrm{Bqm}^{-3} \cdot \mathrm{h}\right), \lambda$ is the decay constant of radon $\left(\mathrm{h}^{-1}\right), V$ is the effective volume of the cup $\left(\mathrm{m}^{3}\right), A$ is the cross section area of the can $\left(\mathrm{m}^{2}\right)$ and $T_{\text {eff }}$ is the effective exposure time [8]. The mass exhalation rate $\left(\mathrm{Bqkg}^{-1} \cdot \mathrm{h}^{-1}\right)$ in the building material samples is calculated using the following formula:

$$
E_{M}=\frac{C V \lambda}{M T_{\text {eff }}}
$$

where, $E_{M}$ is the mass exhalation rate in $\left(\mathrm{Bqkg}^{-1} \cdot \mathrm{h}^{-1}\right)$ and $\mathrm{M}$ is the mass of sample (kg) [8]. The following equation was used to calculate the annual effective dose:

$$
H_{E}\left(\mathrm{mSv} \mathrm{y}^{-1}\right)=C_{R n} \cdot D \cdot F \cdot T
$$

where, $C_{R n}$ in $\mathrm{Bqm}^{-3}$ is the measured mean radon activity concentration in air, $F$ is the indoor equilibrium factor 
between radon and its progeny (0.4), $T$ is time $\left(8760 \mathrm{hy}^{-1}\right)$ and $D$ is the dose conversion factor $9 \mathrm{nSv} / \mathrm{h}$ per $\mathrm{Bq} / \mathrm{m}^{3}$ [9] [10].

\section{Results and Discussion}

Radon concentration, area exhalation rate, mass exhalation rate and annual effective dose for the building materials were given by Table 1 and Table 2 [11]-[18]. The values of radon concentration for black cement ranged from 148.09 - $281.52 \mathrm{Bqm}^{-3}$, area exhalation rate ranged from $190.99-362.88 \mathrm{mBqm}{ }^{-2} \cdot \mathrm{h}^{-1}$, mass exhalation rate ranged from $2.81-4.48 \mathrm{mBqkg}{ }^{-1} \cdot \mathrm{h}^{-1}$ and the annual effective dose varied from $4.67-8.87 \mathrm{mSvy}^{-1}$. Cement (Al-Amserya) has a high values but cement (Al-askeria) has a low values. The values of radon concentration for white cement varied from $60.11-74.78 \mathrm{Bqm}^{-3}$, area exhalation rate ranged from $77.44-96.43 \mathrm{mBqm}^{-2} \cdot \mathrm{h}^{-1}$, mass exhalation rate ranged from $1.16-1.36 \mathrm{mBqkg}{ }^{-1} \cdot \mathrm{h}^{-1}$ and the annual effective dose varied from $1.89-2.35$ $\mathrm{mSvy}^{-1}$. White cement (Sinai) has a low values but white cement (Helwan) has a high values. The values of radon concentration for gypsum varied from 72 - $93.18 \mathrm{Bqm}^{-3}$, area exhalation rate ranged from 92.76 - 120.05 $\mathrm{mBqm}^{-2} \cdot \mathrm{h}^{-1}$, mass exhalation rate ranged from $1.90-2.25 \mathrm{mBqkg}{ }^{-1} \cdot \mathrm{h}^{-1}$ and the annual effective dose varied from 2.27 - $2.93 \mathrm{mSvy}^{-1}$. Gypsum (Al-Medena) has a high values but Al-Bulah has a low values. The values of

Table 1. Radon concentration $\left(C_{R n}\right)$, area exhalation rate $\left(E_{A}\right)$, mass exhalation rate $\left(E_{M}\right)$ and annual effective dose rate $(H)$ for building materials.

\begin{tabular}{|c|c|c|c|c|c|c|}
\hline $\begin{array}{l}\text { Building } \\
\text { Materials }\end{array}$ & No. & Sample Name & $\begin{array}{c}C_{R n} \\
\mathrm{~Bq} \cdot \mathbf{m}^{-3}\end{array}$ & $\begin{array}{c}E_{A} \\
\mathbf{m B q} \cdot \mathbf{m}^{-2} \cdot \mathbf{h}^{-1}\end{array}$ & $\begin{array}{c}E_{M} \\
\mathrm{mBq} \mathrm{Kg}^{-1} \mathbf{h}^{-1}\end{array}$ & $\begin{array}{c}H \\
\mathrm{mSvy}^{-1}\end{array}$ \\
\hline \multirow{5}{*}{ 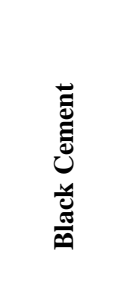 } & 1 & Al-Tamier & $20.52 \pm 201.17$ & $259.19 \pm 25.76$ & $3.30 \pm 0.32$ & 6.34 \\
\hline & 2 & Al-askeria & $17.59 \pm 148.09$ & $190.99 \pm 21.90$ & $2.81 \pm 0.31$ & 4.67 \\
\hline & 3 & Al-Amserya & $18.18 \pm 160.70$ & $207.35 \pm 23.19$ & $3.11 \pm 0.34$ & 5.06 \\
\hline & 4 & Al-Shora & $20.23 \pm 194.72$ & $251.01 \pm 25.76$ & $3.14 \pm 0.34$ & 6.14 \\
\hline & 5 & Al-Mesalh & $24.34 \pm 281.52$ & $362.88 \pm 30.92$ & $4.48 \pm 0.38$ & 8.87 \\
\hline \multirow{4}{*}{ 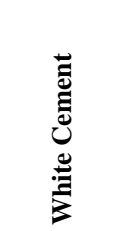 } & 6 & Al-Waha & $21.11 \pm 216.01$ & $278.30 \pm 27.05$ & $3.94 \pm 0.38$ & 6.81 \\
\hline & 1 & Sinai & $11.14 \pm 60.11$ & $77.44 \pm 14.17$ & $1.16 \pm 0.21$ & 1.89 \\
\hline & 2 & Royal & $12.04 \pm 70.38$ & $90.67 \pm 15.46$ & $1.14 \pm 0.19$ & 2.21 \\
\hline & 3 & Helwan & $12.31 \pm 74.78$ & $96.34 \pm 15.46$ & $1.36 \pm 0.21$ & 2.35 \\
\hline \multirow{4}{*}{ 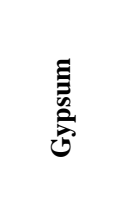 } & 1 & Al-Medena & $14.04 \pm 93.18$ & $120.05 \pm 18.03$ & $2.25 \pm 0.33$ & 2.93 \\
\hline & 2 & Sinai & $12.60 \pm 79.17$ & $102.01 \pm 16.23$ & $1.90 \pm 0.28$ & 2.49 \\
\hline & 3 & Al-Bulah & $12.34 \pm 72.00$ & $92.76 \pm 15.84$ & $2.11 \pm 0.35$ & 2.27 \\
\hline & 4 & Super Sinai & $12.88 \pm 78.35$ & $100.94 \pm 16.49$ & $1.89 \pm 0.29$ & 2.47 \\
\hline \multirow{4}{*}{ 恚 } & 1 & Yellow (Al-Sharqia) & $21.06 \pm 222.28$ & $286.48 \pm 27.05$ & $2.50 \pm 0.23$ & 7.00 \\
\hline & 2 & White (Al-Sharqia) & $19.29 \pm 175.77$ & $226.46 \pm 24.47$ & $2.28 \pm 0.24$ & 5.54 \\
\hline & 3 & Yellow (K. Hamada) & $26.70 \pm 336.65$ & $433.22 \pm 33.49$ & $4.10 \pm 0.31$ & 10.61 \\
\hline & 4 & White (K. Hamada) & $23.10 \pm 252.01$ & $324.68 \pm 29.63$ & $3.09 \pm 0.28$ & 7.94 \\
\hline \multirow{5}{*}{ Uूّ } & 1 & Cleopatra & $15.56 \pm 114.35$ & $147.32 \pm 19.32$ & $2.00 \pm 0.26$ & 3.60 \\
\hline & 2 & Al-Amear & $14.82 \pm 103.77$ & $133.69 \pm 18.03$ & $2.03 \pm 0.27$ & 3.27 \\
\hline & 3 & Alpha & $11.40 \pm 61.41$ & $79.12 \pm 14.68$ & $0.87 \pm 0.15$ & 1.93 \\
\hline & 4 & Al-Jeoharia & $14.04 \pm 93.18$ & $120.05 \pm 18.08$ & $1.52 \pm 0.22$ & 2.93 \\
\hline & 5 & Royal & $14.82 \pm 103.77$ & $133.69 \pm 19.09$ & $1.67 \pm 0.22$ & 3.27 \\
\hline
\end{tabular}


Table 2. Radon concentration $\left(C_{R n}\right)$, area exhalation rate $\left(E_{A}\right)$, mass exhalation rate $\left(E_{M}\right)$ and annual effective dose rate $(H)$ for building materials.

\begin{tabular}{|c|c|c|c|c|c|c|}
\hline $\begin{array}{l}\text { Building } \\
\text { Materials }\end{array}$ & No. & Sample Name & $\begin{array}{c}C_{R n} \\
\mathbf{B q} \cdot \mathbf{m}^{-3}\end{array}$ & $\begin{array}{c}E_{A} \\
\mathbf{m B q} \cdot \mathbf{m}^{-2} \cdot \mathbf{h}^{-1}\end{array}$ & $\begin{array}{c}E_{M} \\
\mathbf{m B q} \cdot \mathrm{Kg}^{-1} \cdot \mathbf{h}^{-1}\end{array}$ & $\begin{array}{c}H \\
\text { mSvy }^{-1}\end{array}$ \\
\hline \multirow{4}{*}{ 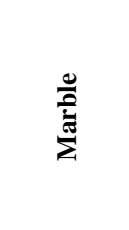 } & 1 & Cecilia (Italian) & $22.16 \pm 241.34$ & $311.04 \pm 28.55$ & $3.57 \pm 0.32$ & 7.61 \\
\hline & 2 & Amblador (Spain) & $20.20 \pm 192.66$ & $248.28 \pm 26.02$ & $2.86 \pm 0.29$ & 6.07 \\
\hline & 3 & White (Turkish) & $24.42 \pm 281.52$ & $362.88 \pm 31.46$ & $3.87 \pm 0.33$ & 8.87 \\
\hline & 4 & Green (Indian) & $18.46 \pm 160.70$ & $207.35 \pm 23.70$ & $2.65 \pm 0.29$ & 5.06 \\
\hline \multirow{4}{*}{ 党 } & 1 & White Cement & $15.84 \pm 118.47$ & $152.79 \pm 20.35$ & $1.67 \pm 0.21$ & 3.73 \\
\hline & 2 & Red & $18.58 \pm 163.06$ & $210.08 \pm 23.83$ & $2.68 \pm 0.29$ & 5.14 \\
\hline & 3 & Thermal & $16.54 \pm 129.03$ & $166.43 \pm 21.25$ & $2.01 \pm 0.25$ & 4.06 \\
\hline & 4 & Jerry & $14.36 \pm 97.36$ & $125.50 \pm 18.42$ & $1.46 \pm 0.21$ & 3.07 \\
\hline \multirow{2}{*}{ 苛 } & 1 & Hash (Egyptian) & $26.61 \pm 334.60$ & $431.09 \pm 34.27$ & $5.49 \pm 0.42$ & 10.55 \\
\hline & 2 & Maica (Egyptian) & $25.50 \pm 307.07$ & $395.62 \pm 32.85$ & $4.20 \pm 0.43$ & 9.68 \\
\hline \multirow{4}{*}{ गे } & 1 & Al-Sharqei (Ataka) & $17.59 \pm 146.04$ & $188.25 \pm 22.54$ & $1.77 \pm 0.20$ & 4.60 \\
\hline & 2 & Al-Sharqei (Salehia) & $12.52 \pm 74.12$ & $95.49 \pm 16.10$ & $1.07 \pm 0.17$ & 2.33 \\
\hline & 3 & $\begin{array}{c}\text { Asharqei } \\
\text { (Abu Hammad) }\end{array}$ & $15.27 \pm 110.12$ & $141.87 \pm 19.58$ & $1.54 \pm 0.21$ & 3.47 \\
\hline & 4 & Kom Hamada & $16.94 \pm 135.48$ & $174.61 \pm 21.77$ & $1.84 \pm 0.21$ & 4.27 \\
\hline \multirow{4}{*}{ 苞 } & 1 & Rose & $36.49 \pm 590.61$ & $761.24 \pm 46.89$ & $7.72 \pm 0.47$ & 18.62 \\
\hline & 2 & Jandola & $1319.06 \pm 52.81$ & $1699.46 \pm 66.99$ & $19.38 \pm 0.76$ & 41.59 \\
\hline & 3 & Ghazal & $36.12 \pm 616.12$ & $793.98 \pm 46.51$ & $8.03 \pm 0.46$ & 19.42 \\
\hline & 4 & Maltk Brown & $855.42 \pm 42.56$ & $1102.32 \pm 54.11$ & $11.07 \pm 0.54$ & 26.97 \\
\hline
\end{tabular}

radon concentration for sand varied from 175.77 - $336.65 \mathrm{Bqm}^{-3}$, area exhalation rate ranged from 226.46 $433.22 \mathrm{mBqm}^{-2} \cdot \mathrm{h}^{-1}$, mass exhalation rate ranged from $2.28-4.10 \mathrm{mBqkg}^{-1} \cdot \mathrm{h}^{-1}$ and the annual effective dose varied from 5.54 - $10.61 \mathrm{mSvy}^{-1}$. Yellow sand (Al-Sharqia) has a high values but white sand (Al-Sharqia) has a low values.

The values of radon concentration of ceramic ranged from $61.41-114.35 \mathrm{Bqm}^{-3}$, area exhalation rate ranged from $79.12-147.32 \mathrm{mBqm}{ }^{-2} \cdot \mathrm{h}^{-1}$, mass exhalation rate ranged from $0.87-2.03 \mathrm{mBqkg} \cdot \mathrm{h}^{-1}$ and the annual effective dose varied from 1.93 - $3.60 \mathrm{mSvy}^{-1}$. Kilopatra ceramic has a high values but alpha has a low values. The values of radon concentration for marble varied from $160.70-281.52 \mathrm{Bqm}^{-3}$, area exhalation rate ranged from 207.35 - $362.88 \mathrm{mBqm}{ }^{-2} \cdot \mathrm{h}^{-1}$, mass exhalation rate ranged from $2.66-3.87 \mathrm{mBqkg}{ }^{-1} \cdot \mathrm{h}^{-1}$ and the annual effective dose varied from 5.06 - $8.87 \mathrm{mSvy}^{-1}$. White marble (Turkish) has a high values but green marble (Indian) has a low values.

Radon concentration for bricks varied from 97.36 - $163.06 \mathrm{Bqm}^{-3}$, area exhalation rate ranged from 125.50 $210.08 \mathrm{mBqm}^{-2} \cdot \mathrm{h}^{-1}$, mass exhalation rate ranged from $1.46-2.68 \mathrm{mBqkg}{ }^{-1} \cdot \mathrm{h}^{-1}$ and the annual effective dose varied from 3.07 - $5.14 \mathrm{mSvy}^{-1}$. Red brick has a high values but jerry brick has a low values.

Radon concentration for stone ranged from 307.07 - $334.60 \mathrm{Bqm}^{-3}$, area exhalation rate ranged from 395.62 $431.09 \mathrm{mBqm}^{-2} \cdot \mathrm{h}^{-1}$, mass exhalation rate ranged from $4.20-5.49 \mathrm{mBqkg}^{-1} \cdot \mathrm{h}^{-1}$ and the annual effective dose varied from 9.68 - $10.55 \mathrm{mSvy}^{-1}$. Hash (Egyptian) has a high values but mica (Egyptian) has a low values. The values of radon concentration for gravel varied from 74.12 - $146.04 \mathrm{Bqm}^{-3}$, area exhalation rate ranged from 95.49 - $188.25 \mathrm{mBqm}^{-2} \cdot \mathrm{h}^{-1}$, mass exhalation rate ranged from $1.07-1.84 \mathrm{mBqkg}{ }^{-1} \cdot \mathrm{h}^{-1}$ and the annual effective dose varied from 2.33 - $4.60 \mathrm{mSvy}^{-1}$. Ataka gravel has a high values but Salehia gravel has a low values. Radon concentration for granite varied from 590.61 - $1319.06 \mathrm{Bqm}^{-3}$, area exhalation rate ranged from 761.24 1699.46 $\mathrm{mBqm}^{-2} \cdot \mathrm{h}^{-1}$, mass exhalation rate from $7.72-19.38 \mathrm{mBqkg}{ }^{-1} \cdot \mathrm{h}^{-1}$ and the annual effective dose varied 
from 18.62 - $41.59 \mathrm{mSvy}^{-1}$. Granite (Jandola) has a high values but granite (rose) has a low values.

The average values of radon concentration, area exhalation rate, mass exhalation rate and annual effective dose for building materials were given by Table 3 . The average values of radon concentration for building materials ranged from $68.42-845.43 \mathrm{Bqm}^{-3}$, surface exhalation rate from $88.15-1089.25 \mathrm{mBqm}^{-2} \cdot \mathrm{h}^{-1}$, mass exhalation rate varied from $1.22-11.55 \mathrm{mBqkg}{ }^{-1} \cdot \mathrm{h}^{-1}$ and the average value of annual effective dose varied from $2.05-25.58 \mathrm{mSvy}^{-1}$ as shown in Table 3. From the obtained results the values of granite samples higher than the other building materials but the white cement has a low values. Figure 1, shows the comparison between the values of radon concentration for different building materials. Also the comparison between the values of area exhalation rate for the samples was given by Figure 2. The correlation relation between radon concentration and area exhalation rate is a good linearity relation and the correlation coefficient $R^{2}=1$ as shown in Figure 3 . The

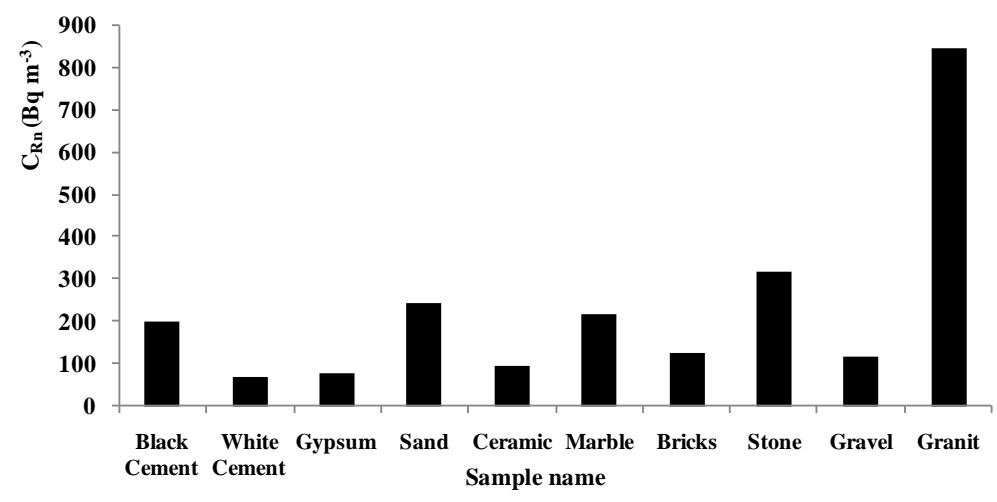

Figure 1. The relation between the sample name and radon concentration $\left(C_{R n}\right)$ of the building materials.

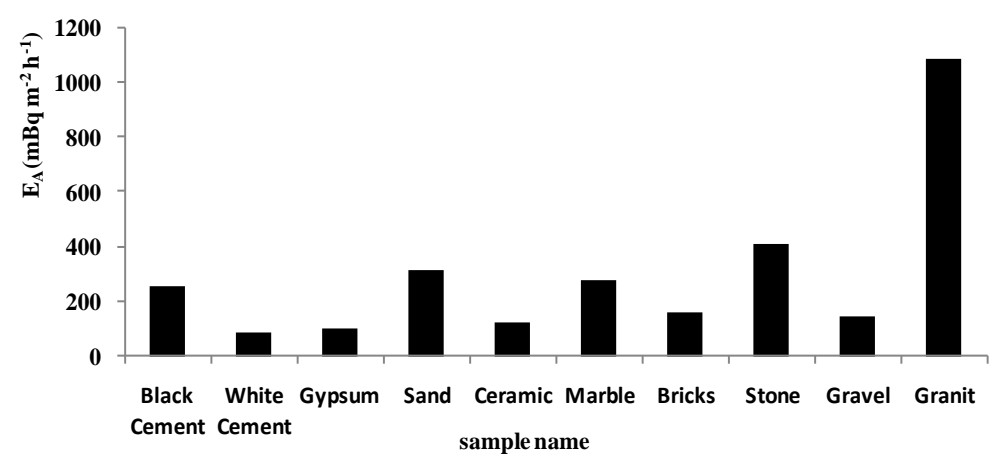

Figure 2. The relation between the sample name and area exhalation rate $\left(E_{A}\right)$ of the building materials.

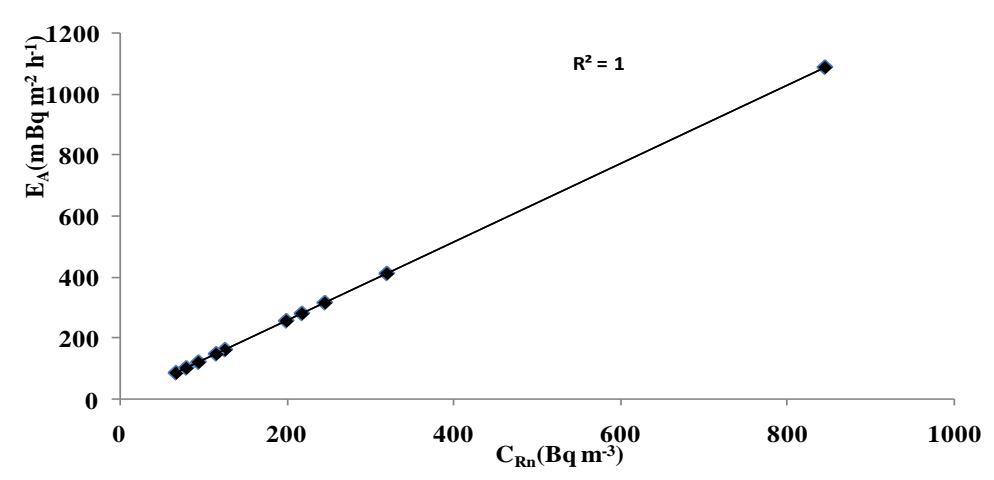

Figure 3. The correlation between radon concentration $\left(C_{R n}\right)$ and area exhalation rate $\left(E_{A}\right)$ of the building materials. 
comparison between the average values of annual effective dose for the measured samples as shown Figure 4. From the obtained figure we find that the average annual effective dose rate of granite samples have a high values and white cement samples have a low values.

\section{Conclusions}

This study can be used to assess any changes in the radioactive background level in our houses in order to detect any harmful radiation effects on human and establish a data base for building materials which, is used in a local market.

The average values of radon concentration varied from $68.42-845.43 \mathrm{Bqm}^{-3}$ and exhalation rate varied from $88.15-1089.25 \mathrm{Bqm}^{-2} \cdot \mathrm{h}^{-1}$. From the obtained experimental results, we found that granite samples have a high values, while the lowest average values is white cement. The values of radon concentration and exhalation rate were varied from sample to another due to the variation in the chemical composition of the sample.

The obtained results show that the values of radon concentrations of the most samples are below the allowed limit from ICRP while granite samples higher are than the recommended limit. The International Commission on Radiological Protection recommended that a radon concentration from 200 to $600 \mathrm{Bqm}^{-3}$ for dwelling [19]. Comparison the present work with results obtained in other parts of the world given by Table 4. The ventilation

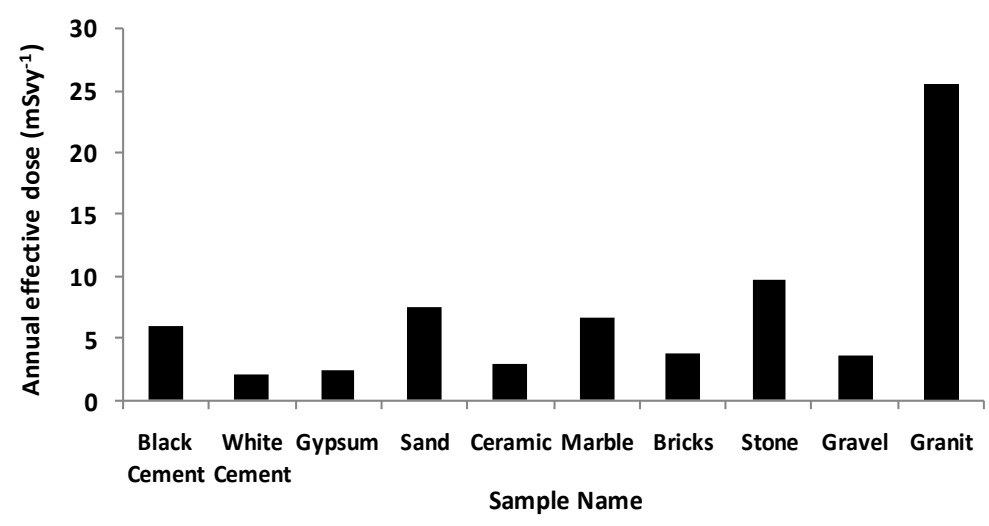

Figure 4. The comparison between annual effective dose and samples of building materials.

Table 3. The average values of radon concentration $\left(C_{R n}\right)$, area exhalation rate $\left(E_{A}\right)$, mass exhalation rate $\left(E_{M}\right)$ and annual effective dose $\left(H_{E}\right)$ for building materials.

\begin{tabular}{ccccc}
\hline Building Materials & $\boldsymbol{C}_{R \mathbf{n}}\left(\mathbf{B q} \cdot \mathbf{m}^{-3}\right)$ & $\boldsymbol{E}_{\boldsymbol{A}}\left(\mathbf{m B q} \cdot \mathbf{m}^{-2} \cdot \mathbf{h}^{-\mathbf{1}}\right)$ & $\boldsymbol{E}_{M}\left(\mathbf{m B q} \cdot \mathbf{K g}^{-1} \cdot \mathbf{h}^{-1}\right)$ & $\left.\left.H_{(\mathbf{m S v y}}\right)^{-1}\right)$ \\
\hline Black Cement & 200.47 & 258.28 & 3.46 & 6.32 \\
White Cement & 68.42 & 88.15 & 1.22 & 2.15 \\
Gypsum & 80.67 & 103.94 & 2.03 & 2.54 \\
Sand & 246.60 & 317.71 & 2.99 & 3.77 \\
Ceramic & 95.29 & 122.77 & 1.61 & 6.90 \\
Marble & 219.18 & 282.38 & 3.23 & 4.00 \\
Bricks & 127.06 & 163.70 & 1.95 & 10.11 \\
Stone & 320.83 & 413.35 & 4.84 & 3.67 \\
Gravel & 116.47 & 150.05 & 1.55 & 26.65 \\
Granit & 845.43 & 1089.25 & 11.55 & \\
\hline
\end{tabular}


Table 4. The comparison between the obtained experimental results and the published data for building materials in different countries.

\begin{tabular}{|c|c|c|c|c|}
\hline Country/Org. & Building Materials & $C_{R n}\left(\mathrm{Bqm}^{-3}\right)$ & $E_{A}\left(\mathrm{Bqm}^{-2} \cdot \mathbf{h}^{-1}\right)$ & References \\
\hline Egypt & Cement & & $0.254-0.755$ & {$[11]$} \\
\hline Egypt & Granit Sand & 25024 & & {$[12]$} \\
\hline Egypt & Brick Marble Ceramic & $107-277100-29887$ - 275 & $\begin{array}{c}0.082-0.2100 .076-0.226 \\
0.066-0.208\end{array}$ & [13] \\
\hline Iraq & Brick & $55-162$ & & {$[14]$} \\
\hline Iraq & Cement & 105 & & {$[1]$} \\
\hline Pakistan & Bricks Cement Marble Sand & & 0.2120 .2310 .1200 .292 & {$[15]$} \\
\hline India & Stone Cement & 518 - $941403-538$ & $0.41-0.750 .32-0.43$ & {$[16]$} \\
\hline KSA & Granit & & $0.33-1.25$ & [17] \\
\hline Greek & Granit & & $1.24-3.54$ & [18] \\
\hline ICRP & & $200-600$ & & [19] \\
\hline Egypt & $\begin{array}{l}\text { Black Cem. White Cem. } \\
\text { Gypsum Sand Ceramic Marble } \\
\text { Bricks Stone Gravel Granit }\end{array}$ & $\begin{array}{c}200.4768 .4280 .67246 .60 \\
95.29219 .18127 .06320 .83 \\
116.47845 .43\end{array}$ & 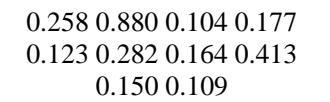 & The present study \\
\hline
\end{tabular}

rate in the houses is very important role in controlling and protection from indoor radon.

\section{References}

[1] Karim, M.S., Abdullah, M.H. and Abass, W.H. (2012) Measurement of Radon Gas Concentration in Cement Samples by Using Nuclear Track Detector (CR-39). Diyala Journal for Pure Sciences, 8, 2222-8373.

[2] Singh, A.K., Ashavani, K. and Rajendra, P. (2006) Distribution of Radon Levels in Udaipur. Asian Journal of Chemistry, 18, 3408-3411.

[3] Ramola, R.C. and Choubey, V.M. (2003) Measurement of Radon Exhalation Rate from Soil Samples of Garhwali Himalaya India. Journal of Radioanalytical and Nuclear Chemistry, 256, 219-223. http://dx.doi.org/10.1023/A:1023920930746

[4] Popovic, D. and Todorovic, D. (2006) Radon Indoor Concentrations and Activity of Radionuclide’s in Building Materials in Serbia. Physics, Chemistry \& Technology, 4, 11-20.

[5] Moharram, B.M., Suliman, M.N., Zahran, N.F., Shennawy, S.E. and El Sayed, A.R. (2012) ${ }^{238}$ U, ${ }^{232}$ Th Content and Radon Exhalation Rate in Some Egyptian Building Materials. Annals of Nuclear Energy, 45, 138-143. http://dx.doi.org/10.1016/j.anucene.2012.03.008

[6] Sarma, H.K. (2013) Radon Activity and Radon Exhalation Rates from Some Soil Samples by Using SSNTD. International Journal of Advanced Research in Electrical, Electronics and Instrumentation Engineering, 2, 2320-3765.

[7] Hamza, V.Z. and Mohan Kumar, M.N. (2009) Cytogenetic Damage in Human Blood Lymphocytes Exposed in Vitro to Radon. Mutation Research, 6, 1-9. http://dx.doi.org/10.1016/j.mrfmmm.2008.10.010

[8] Abd-Elzaher, M. (2012) An Overview on Studying ${ }^{222}$ Rn Exhalation Rates Using Passive Technique Solid State Nuclear Track Detectors. American Journal of Applied science, 9, 1653-1659. http://dx.doi.org/10.3844/ajassp.2012.1653.1659

[9] Ali, K. Alsaedi, B., Almayahi, A. and Alasadi, A.H. (2013) Cement ${ }^{222} \mathrm{Rn}$ and ${ }^{226} \mathrm{Ra}$ Concentration Measurements in Selected Samples from Different Companies. Asian Journal of Natural and Applied Sciences, 2, 195-200.

[10] El-Zain, A.-E.A. (2014) A Study of Indoor Radon Levels and Radon Effective Dose in Dwelling of Some Cities of Gezira State in Sudan. Journal of Nuclear Technology and Radiation Protection, 29, 307-312. http://dx.doi.org/10.2298/NTRP1404307E

[11] El-Bahi, S.M. (2004) Assessment of Radioactivity and Radon Exhalation Rate in Egyptian Cement. Health Physics, 86, 517-522. http://dx.doi.org/10.1097/00004032-200405000-00008

[12] El-Arabi, A.M., Abbady, A., Ahmed, N.K., Michel, R., El-Kamel, A.H. and Abbady, A.G.E. (2006) Assessment of Radon-222 Concentrations and Exhalation Rates of Rocks and Building Materials. Indian Journal of Pure and Applied 
Physics, 44, 287-291.

[13] Saad, A.F., Abdalla, Y.K., Hussein, N.A. and Elyaseery, I.S. (2010) Radon Exhalation Rate from Building Materials Used on the Garyounis University Campus, Benghazi, Libya. Turkish Journal of Engineering Environmental Sciences, 34, 67-74.

[14] Al-Attabi, H.D.Z. (2014) Measurement Radon Concentration in the Iraqi Building Materials: Brick Samples. International Journal of Application or Innovation in Engineering and Management, 3, 2319-2327.

[15] Faheema, M. and Matiullahb (2008) Radon Exhalation and Its Dependence on Moisture Content from Samples of Soil and Building Materials. Radiation Measurements, 43, 1458-1462. http://dx.doi.org/10.1016/j.radmeas.2008.02.023

[16] Gupta, M., Saini, M. and Chauhan, R.P. (2009) Measurement of Alpha Radioactivity in Some Building Construction Materials. Asian Journal of Chemistry, 21, 52-55.

[17] Tufail, M., Nasim, A. and Waqas, M. (2006) Measurement of Terrestrial Radiation for Assessment of Gamma Dose from Cultivated and Barren Saline Soils of Faisalabad in Pakistan. Radiation Measurements, 41, 443-451. http://dx.doi.org/10.1016/j.radmeas.2005.10.007

[18] Stoulos, S., Manolopulou, M. and Papastefanou, C. (2003) Assessment of Natural Radiation Exposure and Radon Exhalation from Building Materials in Greece. Journal of Environmental Radioactivity, 69, 225-240. http://dx.doi.org/10.1016/S0265-931X(03)00081-X

[19] ICRP (1993) Protection against Radon at Home and at Work. Ann., ICRP 23, Publication 65, Pergamon, Oxford. 